\title{
Public's Perception of Halal Food Tourism at Speciality Restaurants in Bandung
}

\author{
R Vindy Melliany Puspa ${ }^{1 *}$, Pandu Hyangsewu² \\ 1STBA YAPARI-ABA Bandung \\ ${ }^{2}$ Universitas Pendidikan Indonesia \\ vindymellianypuspa@gmail.com
}

\begin{abstract}
This study aims to reveal the public's perception and the management's perspective about halal food tourism at speciality restaurants in Bandung. The background of this study is there are still many producers of food products that are not necessarily halal and are not yet certified by halal authorities (MUI) but they have claimed to be halal with the perception of their producers. This research uses a qualitative method. The results showed that some respondents still did not understand very well that related to the concept of halal food. All respondents agreed that the government and Indonesian Ulema Council (MUI) have a right to issue halal certificates. As for the potential for halal food in Indonesia, it is not evenly distributed, because only a few regions or certain tourist attractions have started to optimize the program. The strategy of developing halal food tourism in Indonesia can certainly be managed by the tourism sector because it is very closely related. The conclusion from this research is that there must be a halal food tourism model so that it can be used as a platform. Therefore, the role of government and society is needed to develop the potential for halal food tourism.
\end{abstract}

Keywords: Halal Food Tourism, Public's Perception, Speciality Restaurants 


\section{A. Introduction}

The development of tourism is growing rapidly and become one of the sectors that can contribute high foreign exchange for the country. Tourism is a variety of tourism activities and is supported by various facilities and services provided by the community, entrepreneurs and the regional government (Republic of Indonesia Law No. 10 of 2009). Tourism as a social tourism, cultural and economic phenomenon which entails the movement of people to countries or places outside their usual environment for personal or business/professional purposes, these people are called visitors (which may be either tourists or excursionists; residents or non-residents) and tourism has to do with their activities, some of which imply tourism expenditure (UNWTO, 2018). Therefore, the tourism sector will be increasing and developing in many countries in the world.

The extent to which tourism contributes to the national or local economy or, more generally, to development varies according to a variety of factors (Sharpley \& Tefler, 2015). Indonesian Tourism Industry as a potential, ranging from natural Indonesia has a lot of natural beauty, cultural richness, languages, especially Indonesia strategic geographical location and safe that is able to attract domestic tourists and foreign travelers. As a country that won the overall champion in the event WHAT (World Halal Tourism Award) in 2015, who has won three categories at once from the 15 categories contested. In 2016 Indonesia also won again in the WHAT competition held in Abu Dhabi, United Arab Emirates. Now, Indonesia managed to snatch victory 12 categories from 16 categories were contested in Yunadi/National Geographic Indonesia on December 7th 2016 a rapid advances and proud to Indonesia, but ironically the people of Indonesia themselves are still in doubt even do not know how the quality of the products they purchase and consumption both raw and processed products in Indonesia.

As according to Ni'am Asrorun Soleh as head of Shariah Committee of the World Halal Food Council /Indonesian Ulema Council Commission, Fatwa Center, he explained that halal matters were not specific to religious matters, but had become an accepted global trend in economic, identity and health aspects. Halal is a value that can be accepted by the whole community. With the halal products all communities could be involved, but if there is no legal guarantee there will be barriers to people who only consume halal products. Countries that do not have a foundation of Islamic teachings such as Australia and New Zealand have given attention to the issue of halal for example, related to animal slaughter. Even at the World Halal Food Council, the Mayor of Rome firmly stressed that Rome is seriously developing products with halal certificates with the aim of wanting to be accepted globally as a city that relies on the tourism sector (Fitria, 2017).

Bandung is one of the cities designated as culinary tourism destinations featured by the Ministry of Tourism Focus Group Discussion Manuscript preparation Potential and Spa Wakatobi from Nine destination culinary tourism in Indonesia, namely Bukit Tinggi, Palembang, Yogyakarta, Solo, Semarang, Surabaya, Malang, Bali and Makassar (Turgarini, 2017). As a large city with multicultural citizens, there are various types of food available in Bandung, making the city of Bandung have a variety of food places, from ordinary street food to large classy restaurants. European,

Tourism Research Journal, Volume 5 (1), 2021 
Japanese, Chinese, American, Korean foods that are side by side with food from various parts of the countries.

The importance of public understanding, especially consumers of halal food, is very much needed. This is due to the fact that the majority of food and beverage producers are non-Muslim, whose care and commitment to halal food are difficult to expect (Sopa, 2013).

\section{B. Literature Review}

The development of tourism is currently a business opportunity for some parties. Therefore, there are many businesses that provide great benefits in the field of tourism, one of the types of tourism is culinary tourism. Related about it, food is one example of a local cultural resource that has the potential to facilitate a number of community benefits (Giampiccoli \& Kalis, 2012). Moreover, tourist visiting a particular cultural destination in addition to participating in the knowledge of their heritage, want to increase their sensory experience mainly through gaastronomy. In this sense, gastronomy and its relation to tourism has become a key aspect 14 in the analysis of tourist destinations, especially those relatted to culture and heritage (Betran et al, 2016). From this statement, it can be concluded that people who are going on a tour or tourits visiting a destination culture, apart from participating in knowledge about culture. There also wish to enhance the sensory experience especially the experience trough food. So, this food is related to tourism especially with the local culture.

As explained before, food tourism has a chance in the future. Food tourism as a collective discourse bind farmer, producer, distributor, retailer and consumer together thus providing stakeholder and communities a utopian vision of the future (Yoeman \& Beatte, 2016). Culinary tourism as part of a tourism strategy for a local has received growing support (Harrington \& Ottenbacher, 2010). The other expert describe about culinary tourism that culinary tourism is the international exploratory participant in the foodways of an other item, cuisine, meal system, or eating style considered belong to a culinary system not ones own. From this explanation, it can be assumed that culinary tourism is an exploratory activity in consuming food, preparing and presenting food items, cooking, eating systems and eating methods. Furthermore, culinary tourism similarly is a negotiation between the exotic and the familiar. The food need to be novel, strange, or different enough to stir curiosity, but familiar enough to be recognizable as an edivle substance (Long, 2010). That attraction can be used as a tourist activity. Therefore, not often food and drink in a place makes tourits an excuse to come and visit that place.

Sharia tourism is part of the halal industry which becomes one of the major supporters of the sharia economy in Indonesia. Nevertheless, since 2011, the city of Bandung as the epicentrum of sharia tourism experienced a decreasing number of visitors. Every change in safety, comfort and service will affect the tourist interest on attractions and the visitors, moreover, service, safety and comfort and promotion are simultaneously affect the interest of visiting sharia tourism (Srisusilawati, 2020). From the description, Shariah tourism is used by many people because characteristics of products and services that are universal. Tourism products and services, tourist

Tourism Research Journal, Volume 5 (1), 2021 
objects, and tourist destinations in Islamic tourism are the same as the object and destinations service products in general as long as they do not conflict with shariah values and ethics. So, this sharia tourism is not limited to religious tourism only.

Halal, which means "permissible" or "allowed" in Arabic, is essentially a way of life and is not solely confined to the types of food that a Muslim is allowed to consume, though food is a vital component for the sustenance needed to lead a meaningful life. The bottom line is that Halal food is not just about what the food is but how it is prepared. The Halal concept emphasizes safety, hygiene and wholesomeness of food. It also provides an excellent platform for healthy eating. Consideration of the place and process of the animals being slaughtered and most importantly, the condition of these animals would not endanger the health of diners, are a prime focus of what Halal is all about. Today, Halal is no longer a mere religious obligation or observance, but is considered as the standard of choice for Muslims as well as non-Muslims worldwide. The Halal concept is not unfamiliar to non-Muslims, especially those in Muslim countries (Golnaz, 2010).

In addition, the purposes of this research are to find out the public's perception of halal food at speciality restaurants especially in Javanese and Koran resataurants. The difference between this study and previous research is to describe the manager's perspective on halal food tourism.

\section{Research Methodology}

This research was conducted by survey and interview methods. Determination of sampling in this study using non probability sampling method, this method was chosen because not all members of the population have the same opprtunity as respondents. A sample is a subset of a population and within the context, the notion of non-probability sampling denotes the absence of probability sampling mechanism (Wolf et al, 2016).

\section{Population and Sample}

The population in this research on the analysis of public perceptions of halal food in Bandung is the consuments and the managements in some restaurants, such as Japanese restaurants and Korean restaurants. The total respondents in Japanese restaurants are 2 consumers and 2 managements in Morugame-Udon and Sumoboo restaurants, while the number of respondents in Korean restaurants is 2 consumers and one person from the restaurant management (Mo-guri restaurant).

\section{Data Collection Technique}

The data collection technique used is qualitative. To collect data on this research, the researchers used the following data collection techniques:

1. Literature study, from the study of literature collected is in the form of data secondary, review of source books, as well as from previous studies.

2. Observation/survey, in this technique the writers went directly to several restaurants in Bandung which is the object of the research.

3. Interview, the interview is one of the data collection methods to obtain data information by interviewing directly related respondents.

Tourism Research Journal, Volume 5 (1), 2021 
4. Questionnaire, were distributed with the aim of seeing and knowing the perceptions of the public, namely food producers and consumers about their perceptions of halal food.

\section{Data Analysis}

In this study, data anlysis were taken from the results of a questinnaire containing the perception of comsuments at speciality restaurants in Bandung regarding halal food consisting one the variable, determined by 5 sub variables and indicators for each sub variable. The assesment of indicators uses intervals with strongly agree, agree, less disagree, disagree, and strongly disagree with a Likert's scale value of one to five. In addition, the reserchers collected the results of interviews regarding perceptions of some consumers and restaurant managements towards halal food. After collecting and identfying the data, the data are analysed based on the aims of the research.

\section{Results and Discussion}

\section{Public Perception/Customer's Perception about Halal Food}

After observing several Japanese and korean restaurants, there are 7 respondents (the respondents are 2 consumers and 2 managements in Japanese restaurants, and the total respondents are 2 consumers and one person from the restaurant management in Korean restaurants).

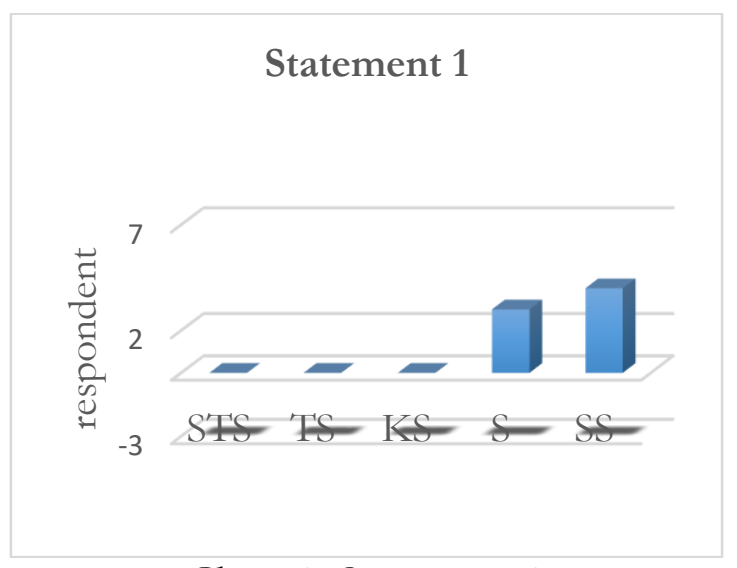

Chart 1. Statement 1

1. Statement 1:

I will choose food products that have halal logo certificates on their packaging. From the chart above can be explained that out of seven respondents who answered strongly agree (SS) 4 and 3 people who answered agreed (S). Thus, the majority of respondents chose food products that have halal logo certificates showing very positive things about consumers' perceptions of choosing halal foods. 


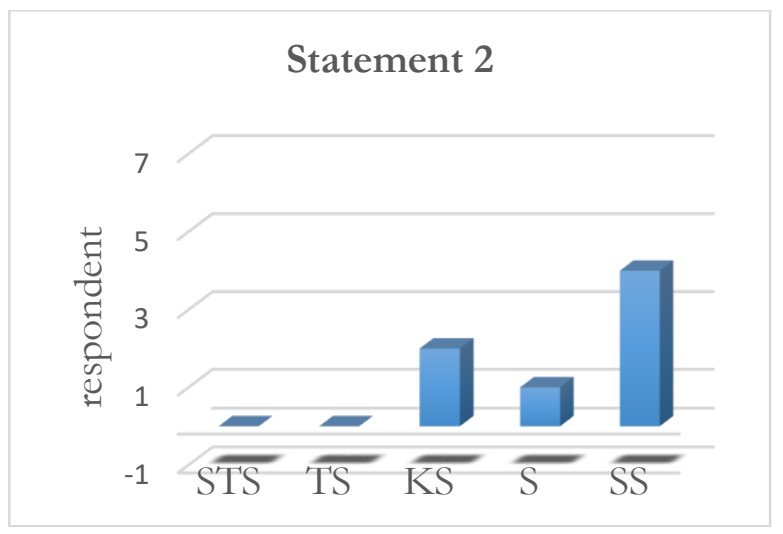

Chart 2. Statement 2

2. Statement 2:

I understand the halal logo printed on food products issued by the authorized certification body. From the chart image 2 shows that of 7 total respondents who answered 4 strongly agree (SS), 1 agree (S), and 2 (KS). From the statements of the respondents it can be concluded that although the majority of community respondents understand the halal logo, there are still some who do not understand the halal logo listed on food products issued by the authorized certification body. Therefore, counseling should be given to the community.

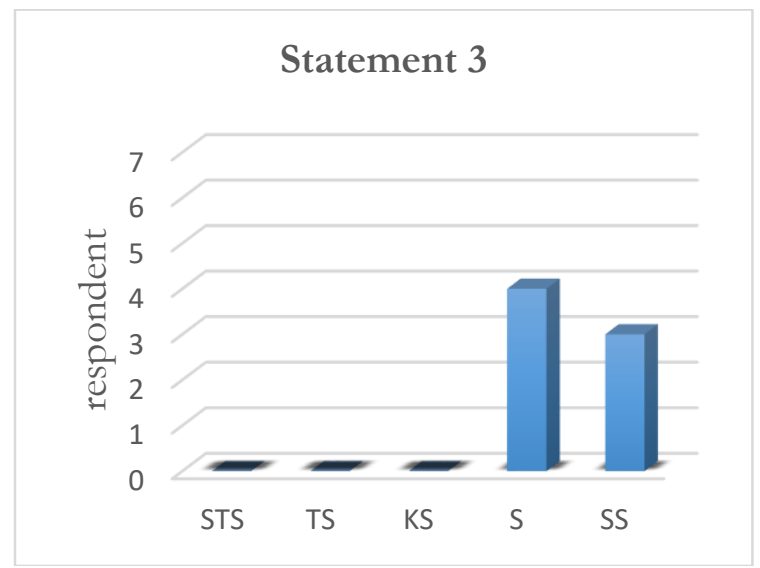

Chart 3. Statement 3

3. Statement 3:

Halal food is food that is not only for Muslims but is related to health reasons. The statement claimed that halal food is food that is not only for Muslims but relate to health reasons, the response was very positive. This is indicated from the statements of respondents who answered agree with 4 people and strongly agree with 3 people. It can be concluded that people's perception of halal food is related to people's understanding that indeed when we consume halal food, it is also related to health. This is also evidenced by some researches on health which is very supportive for selecting all halal products.

Tourism Research Journal, Volume 5 (1), 2021 
Public's Perception of Halal Food Tourism at Speciality Restaurants in Bandung

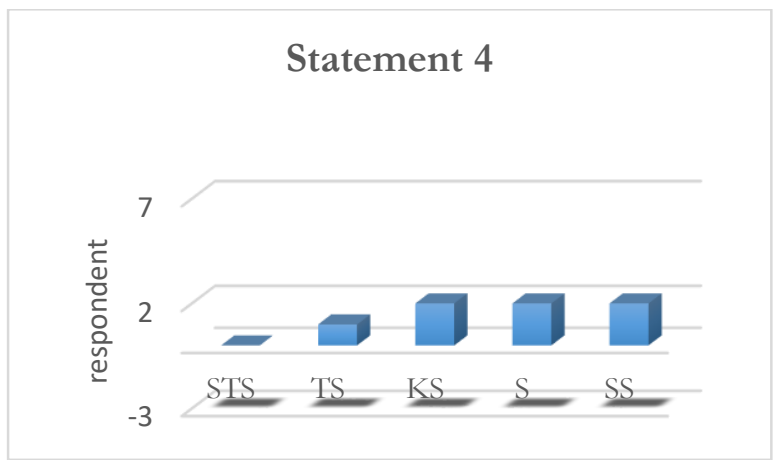

Chart 4. Statement 4

4. Statement 4:

If I doubt the halal nature of the food product, I will buy, I decide not to buy it. All the respondents' statements show that two people answered strongly agree (SS), 2 agree (S), 2 disagree, and 1 agree. Public perception of the doubt will halal food products purchased and decided not to buy it, most expressed a positive thing for not buying. In addition, a small number of respondents who expressed less agree and disagree. It can be concluded that there are still those who decide to buy food products even though there are doubts in the halal of food products.

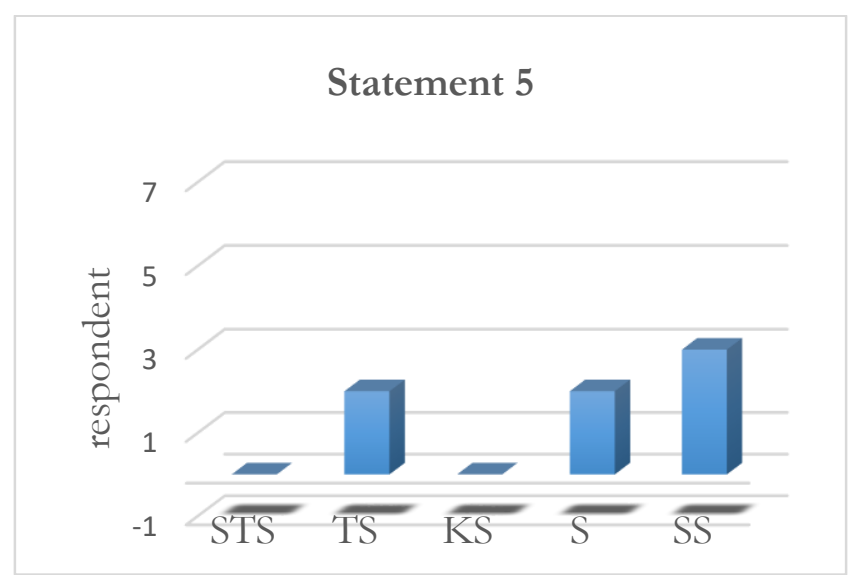

Chart 5 , statement 5

5. Statement 5:

I chose food in packaging that lists the halal logo. Figure chart above can be explained that the three people who answered strongly agree (SS), 2 person who answered agreed (S), and two people who answered disagree (TS). Thus, statements regarding choosing packaged food that lists the halal logo majority expressed positive public perception and a small part will not vote packaged food that lists the halal logo. 
Public's Perception of Halal Food Tourism at Speciality Restaurants in Bandung

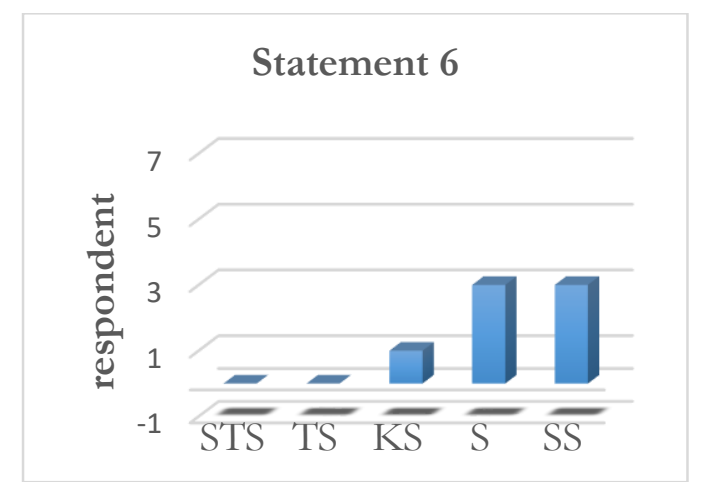

Chart 6. Statement 6

6. Statement 6:

I understand that all meat such as beef, lamb, chicken, etc. are permitted if slaughtered using Islamic law. The statement stating that all meat such as beef, goat, chicken, etc. is halal if slaughtered using Islamic law, 3 people who answered strongly agree (SS), 3 people agreed (S), and 1 person who answered less agree (KS). So, the majority of respondents showed a positive thing in people's perception that every time they slaughter all meat must use Islamic law.

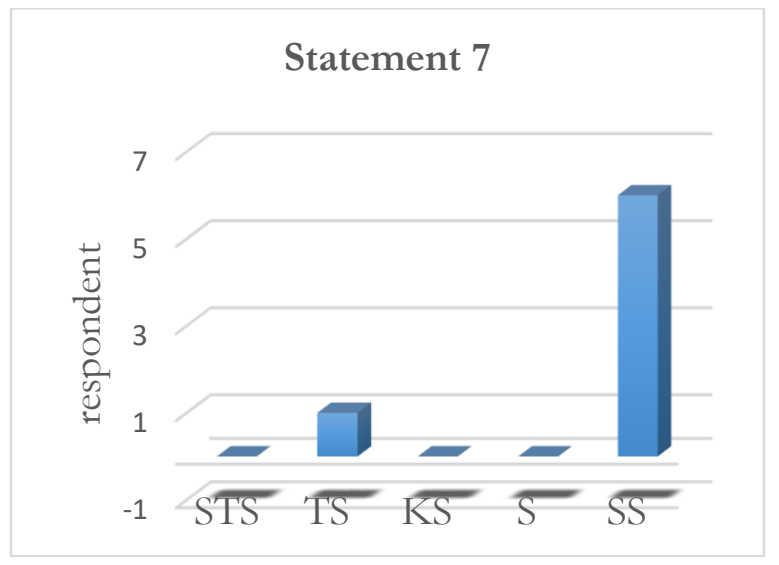

Chart 7. Statement 7

7. Statement 7:

I cook dishes made from processed fish and meat (sausages, meatballs, ham, nuggets, corned beef) whose ingredients do not contain pork. The explanation can be shown that the six people who answered strongly agree (SS) and 1 person who answered disagree (TS). Thus, most people choosed to cook dishes made from processed fish and meat (sausages, meatballs, ham, nuggets, corned beef and pempek) whose raw ingredients do not contain pork.

Tourism Research Journal, Volume 5 (1), 2021 
Public's Perception of Halal Food Tourism at Speciality Restaurants in Bandung

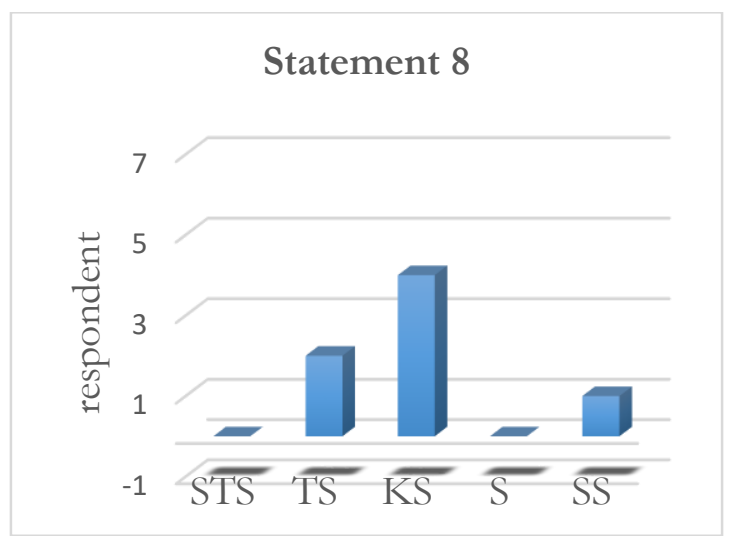

Chart 8. Statement 8

8. Statement 8:

I chose packaged food ingredients in the form of processed meat and processed fish (meatballs, sausages, nuggets, smokebeef, pempek) whose information uses Indonesian language. From the number of respondents who gave their statements, 4 people answered less disagreed (KS), 2 people answered disagreed (TS) and 1 person strongly agreed (SS). The statement shows that the majority disagreed and disagreed in choosing food ingredients contained in packages in the form of processed meat and processed fish (meatballs, sausages, nuggets, smokebeef, pempek) whose information was in Indonesian.

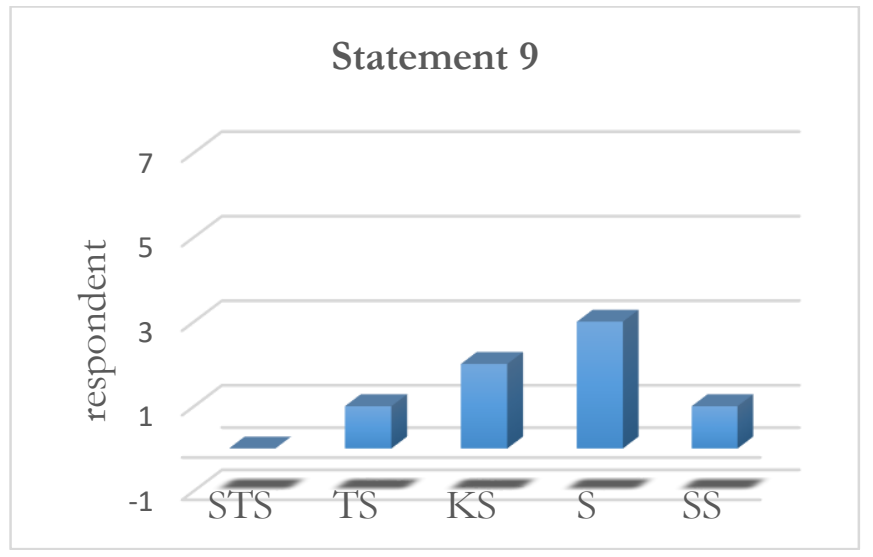

Chart 9. Statement 9

9. Statement 9:

I do not use seasonings (MSG, flavoring, soy sauce, sauce) which do not contain the halal logo on the packaging. Of all the respondents' statements, it shows that 1 person answered strongly agree (SS), 3 agreed (S), 2 disagreed, and 1 agreed. The public perception that dosen not use seasoning (MSG, Flavor, ketchup, sauces) that the packaging does not list the halal logo having many varied answers. It can be concluded that the majority stated very positive things about the use of spices that included the halal logo. But there are still some who decide to keep buying even though there is no halal logo on the seasoning used.

Tourism Research Journal, Volume 5 (1), 2021 


\section{Management Perceptions Regarding Halal Food at Specialty Restaurants}

Retrieval of data obtained by using questionnaires and interviews, researchers interacted with some Korean and Japanese restaurants managements in Bandung, the explanation is following below:

\section{Questionnaire Distribution Results}

From the results of the distribution of the questionnaire obtained that $80 \%$ of respondents strongly agreed to use separate cooking utensils if they process non-halal food (pigs, swikee, bats, etc.) while $20 \%$ of respondents stated strongly disagree in using separate cooking utensils when processing non-halal food (pigs, swike, bat, etc.). This is due to the fact that respondents maintain cleanliness and distinguish cooking utensils that are used for unclean and halal cooking. The $20 \%$ of respondents strongly disagree to use separate cooking utensils if they process non-halal food (pork, swikee, bat, etc.). This is due to the fact that cooking using a tool does not affect the halal or blackness of a food.

The results of the subsequent questionnaire distribution showed that $20 \%$ of respondents strongly disagreed using cutlery which was used separately with halal and non-halal food. With the reason that the cutlery used, must be clean and not affect the type of food. Then obtained as much as $20 \%$ agree in using cutlery that is used separately with halal and non-halal food. Furthermore, as many as $60 \%$ of respondents strongly agreed to use cutlery separately between halal and non-halal foods.

Furthermore, data obtained by $40 \%$ strongly agree in maintaining the kitchen cleanliness where to process food and obtained data as much as $60 \%$ strongly agree from respondents in maintaining the cleanliness of the kitchen where to process food. The data from respondents as much as 60\% strongly agree in maintaining the cleanliness of the dining room where consumers eat food products sold. As much as $40 \%$ agree in maintaining the cleanliness of the dining room where consumers eat food products sold.

\section{Interview Result}

From the results of the interview it can be understood that some respondents still do not understand well assembled with the concept of halal food, this is due to the lack of socialization related to the concept. Although halal food has already existed in the tourism, the tourism should also begin to introduce this concept. All respondents agreed that the government and Indonesian Ulema Council (MUI) were entitled to issue halal certificates. This is certainly an important concern because recently there have been a number of food products that have entered Indonesia without going through halal certification and have been sold in the community.

As for the potential for halal food in Indonesia, of course, it is still unequitable because only a few regions or certain tourist attractions have started to optimize the halal food program. Therefore, It needs the support from various participants and in particular the government. The strategy of developing halal food in Indonesia can certainly be managed by the tourism sector, because it is very closely related, examples

Tourism Research Journal, Volume 5 (1), 2021 
start from lodging, tourist attractions, and also the food.Moreover, there must be a model of halal food tourism in Indonesia so that it can be used as a guideline.

Therefore the role of government and society is needed to develop the potential for halal food. There is no doubt that our country is the majority Muslim population and this has the greatest potential if we have the support from the government.

\section{E. Conclusion}

The main conclusions of this study about the public's perception are the majority of respondents chose halal foods, although there are still some people who don't understand about the halal logo listed on food product. People's perception of halal food is related to people's understanding when they consume halal food, it is also related to health. For the awareness of the public's perception is still less because there are still those who decide to buy food products even though there are doubts in the halal of food products. In addition, the majority of respondents showed a positive thing in people's perception that every time they slaughter all meat must use Islamic law.

Then, the management's perspective about halal food are almost the workers disagreed using cutlery which was used separately with halal and non-halal food, because of, the cutlery must be clean and not affect the type of food halal or non halal. In addition, some respondents still do not understand well assembled with the concept of halal food, this is due to the lack of socialization related to the concept. Although halal food has already existed in the tourism, the tourism should also begin to introduce the concept.

\section{REFERENCES}

Betran, F. J., Guzman, T. L., \& Santacruz, F. G. (2016). Analysis of the Relationship between Tourism and Food Culture. Sustainability Journal, 8 (418): 1-11.

Fitria, N. (2017). Analisis Persepsi Masyakat Terbadap Halal Food Di Kota Bandung. Skripsi. Program Studi Manajemen Industri Katering Fakultas Pendidikan Ilmu Pengetahuan Sosial Universitas Pendidikan Indonesia.

Giampiccoli, A., \& Kalis, J. H. (2012). Tourism, food \& Culture: Community Based Tourism, local food and Community development in Mpondoland. The Journaf of Culture, Agriculture, Food and Environment, 34(2): 101-123.

Harrington, R. J., \& Ottenbacher, M. C. (2010). Culinary Tourism: A case study of the Gastronomic Capital. Journal of Culinary science and Technology, 8(1), 14-32.

Long, L. M. (2010). Comfort Food in Culinary Tourism: Negotiating "Home" as Exotic and Familiar. North Carolina Folklore Journal, 7(1): 1-20.

Golnaz, R., Zainalabidin, M., Mad-Nasir, S., \& Eddie-Chiew, F.C. (2010). NonMuslims' awareness of Halal principles and related food. International Food Research Journal, 17: 667-674.

Republic of Indonesia Law No. 10. Years 2009 about Tourism.

Tourism Research Journal, Volume 5 (1), 2021 
Sharpley, R., \& Tefler, D. J. (2015). Tourism and Development Concepts and Issues. Great Britain: Short Run Press Ltd.

Sopa. (2013). Sertifikasi Halal Majelis Ulama Indonesia: Studi atas fatwa Halal MUI terhadap produk makanan, obat-obatan dan kosmetika. Jakarta: GP Press.

Srisusilawati, P. (2020). Factors Affecting Tourist Interest on Sharia Tourism. AlUqud: Journal of Islamic Economics, 4(2), 200-207.

Turgarini, D. (2017). Penyusunan Naskah Potensi Wisata Kuliner dan Spa Wakatobi (FGD). Jakarta: Kementrian Pariwisata dan Ekonomi Kreatif.

Wolf, C., Joye, D., Smith, T. W., \& Fu, Y. C. (2016). Survey Methodology. London: SAGE Publications Ltd.

Yoeman, I., \& Beatte, U. M. (2016). The future of food tourism. Journal of Tourism Future, 2(1), 95-98.

UNWTO. (2018). Tourism Definitions. Retrieved March 15, 2019, from https://www.unwto.org/global/publication/UNWTO-Tourism-definitions. 